\title{
PENINGKATAN AKTIVITAS DAN HASIL BELAJAR IPS PESERTA DIDIK DENGAN MENGGUNAKAN MEDIA PEMBELAJARAN "SIPETE"
}

\author{
Martina Lona Jusita ${ }^{1}$ \\ Diterima 15 Maret 2018, Dipublikasikan 17 April 2018 \\ CPenulis (2018)
}

\begin{abstract}
Understanding the Subthemes of Nature of Indonesia, especially on sub-theme Flora and Fauna will be more easily understood by learners based on the learning experience gained from the transfer of knowledge submitted by teachers. For that, teachers need to use a medium as an intermediary in learning. The appropriate learning medium is to use "Sipete". It is also expected that the selected learning media can improve the activity and learning outcomes of learners. Based on the results of research proves that the use of learning media "Sipete" can improve the activity and learning outcomes of learners. Evident from each cycle showed a significant improvement. In the first cycle of learning activities, only 15 students (46.88\%) showed high learning activity with the percentage of success reached 57 in enough category, increased to 23 people $(71,88 \%)$ in Cycle II with the success of the action reached 73 in good category. In the third cycle increased to 27 people (84.38\%) which showed high learning activity with the percentage of success reached 82 in very good category.
\end{abstract}

\section{Keywords}

Learning Activity, Learning Outcomes, Learning Media "Sipete"

\section{PENDAHULUAN}

Kurikulum 2013 diimplementasikan secara bertahap mulai tahun pelajaran 2013/2014. Di SMP Negeri 2 Ngantang Kabupaten Malang baru dilaksanakan pada tahun pelajaran 2018/2019. Komponen terpenting implementasi kurikulum adalah pelaksanaan proses pembelajaran yang diselenggarakan di dalam dan/atau di luar kelas untuk membantu peserta didik mencapai kompetensi sikap, pengetahuan dan keterampilan.

Peraturan Menteri Pendidikan dan Kebudayaan Nomor 22 Tahun 2016 tentang Standar Proses yang menyatakan bahwa proses pembelajaran pada satuan pendidikan diselenggarakan secara interaktif, inspiratif, menyenangkan, menantang, memotivasi peserta didik untuk berpartisipasi aktif, serta memberikan ruang yang cukup bagi prakarsa, kreativitas, dan kemandirian sesuai dengan bakat, minat, dan perkembangan fisik serta psikologis peserta didik.

Proses pembelajaran pada prinsipnya adalah mengembangkan aktivitas belajar peserta didik melalui berbagai interaksi dan pengalaman belajar. Aktivitas belajar menurut Rusman (2015) yang mengacu pada belajar kognitif merupakan proses bagaimana menghayati, mengorganisasi, dan mengulang informasi tentang suatu masalah, peristiwa, objek, serta upaya untuk menghadirkan kembali melalui tanggapan, gagasan, atau lambang dalam bentuk kata-kata atau

SMP Negeri 2 Ngantang Kabupaten Malang martinalonajusita@gmail.com 
kalimat. Ciri-ciri aktivitas belajar di antaranya: a) terjadi secara sadar, b) bersifat fungsional, c) positif dan aktif, d) tidak bersifat sementara, e) bertujuan dan terarah, dan f) mencakup seluruh aspek tingkah laku.

Hasil belajar menekankan kepada diperolehnya informasi tentang seberapakah perolehan siswa (peserta didik) dalam mencapai tujuan pengajaran yang ditetapkan (Dimyati, 2009). Selain itu hasil belajar dapat menetapkan baik buruknya hasil dari kegiatan pembelajaran. Untuk menentukan baik buruknya hasil pembelajaran dengan menggunakan tes hasil belajar.

Pemahaman Subtema Kondisi Alam Indonesia khususnya pada Sub-tema Flora dan Fauna di kelas VII akan lebih mudah dipahami oleh peserta didik berdasarkan pengalaman belajar yang diperoleh dari transfer ilmu yang disampaikan oleh guru. Akan tetapi pada saat kegiatan pembelajaran, terlihat peserta didik tidak memiliki dorongan untuk mendalami materi dan cepat-cepat mengakhiri pembelajaran. Kendala lain adalah LCD yang dimiliki sekolah terbatas hanya empat yang bisa digunakan serta dipakai secara bergantian; sedangkan jumlah rombongan belajar 12 kelas. Dengan demikian ketika guru akan menampilkan media sebagai perantara dalam proses pembelajaran untuk membantu peserta didik memahami konsep atau materi melalui LCD; tentunya tidak dapat terlaksana sesuai dengan yang direncanakan. Kenyataan ini berimbas pada aktivitas belajar peserta didik serta pada akhirnya sangat mempengaruhi hasil belajarnya. Dengan demikian diperlukan solusi agar dapat meningkatkan aktivitas dan hasil belajar peserta didik.

Untuk mengatasi kendala yang muncul, guru perlu menggunakan suatu media sebagai perantara dalam pembelajaran. Media pembelajaran adalah alat bantu pada proses belajar baik di dalam maupun di luar kelas, lebih lanjut dijelaskan bahwa media pembelajaran adalah komponen sumber belajar atau wahana fisik yang mengandung materi instruksional di lingkungan siswa (Purnomo, 2017) yang dapat merangsang siswa untuk belajar (Arsyad, 2011). Adapun media pembelajaran yang sesuai adalah menggunakan "Sipete".

"Sipete" merupakan akronim dari Simbol Peta Tempel. Sebelum membahas detail dari Simbol Peta Tempel perlu diketahui definisi dari simbol peta. Menurut Kamus Besar Bahasa Indonesia (2002) simbol adalah lambang atau sesuatu seperti tanda yang menyatakan suatu hal atau mengandung maksud tertentu. Peta adalah gambar atau lukisan pada kertas dan sebagainya yang menunjukkan letak tanah, laut, sungai, dan sebagainya; representasi melalui gambar dari suatu daerah. Dengan demikian simbol peta merupakan lambang atau tanda yang menyatakan suatu hal atau maksud tertentu pada peta. Oleh karena "Sipete" merupakan simbol peta tempel dapat diartikan bahwa simbol peta yang dimaksud digunakan dengan cara ditempelkan pada peta. Diharapkan media pembelajaran yang dipilih dapat membantu proses belajar (self direct learning) yang akhirnya mampu meningkatkan aktivitas dan hasil belajar IPS peserta didik.

\section{METODE}

Penelitian yang dilakukan adalah Penelitian Tindakan Kelas, karena peneliti berusaha memahami apa yang terjadi sambil terlibat dalam sebuah proses perbaikan dan perubahan (Wiriaatmadja, 2009). Peneliti berpartisipasi langsung dalam penelitian mulai tahap awal hingga akhir.

Subjek penelitian adalah peserta didik kelas VII-D SMP Negeri 2 Ngantang Tahun Pelajaran 2017/2018 sejumlah 32 orang. Jumlah peserta didik perempuan 12 dan laki-laki sejumlah 20 orang. Waktu penelitian dilakukan mulai minggu pertama September 2017 sampai dengan 
minggu kedua November 2017. Pengumpulan data dengan menggunakan (a) lembar observasi aktivitas belajar, dan (b) tes hasil belajar IPS.

Prosedur penelitian meliputi: (a) tahap pra tindakan, dan (b) tahap pelaksanaan tindakan yang terdiri dari tiga siklus. Setiap siklus dilakukan perencanaan (plan), pelaksanaan (action), observasi (observation), dan refleksi hasil tindakan (reflection).

Selengkapnya langkah-langkah kegiatan adalah tahap awal dimulai dengan menyiapkan instrumen penelitian, Rencana Pelaksanaan Pembelajaran (RPP), dan membuat media pembelajaran "Sipete". Langkah selanjutnya dalam pelaksanaan pembelajaran pada materi Flora dan Fauna dengan menggunakan media pembelajaran "Sipete" sekaligus selama berlangsungnya proses pembelajaran melakukan kegiatan pengamatan dan dokumentasi datadata yang berkaitan dengan aktivitas dan hasil belajar IPS peserta didik. Guru menjelaskan materi Flora dan Fauna tentang karakteristik, jenis dan sebarannya dengan menggunakan "Sipete". Berikutnya peserta didik melakukan diskusi secara berkelompok, setelah selesai masing-masing perwakilan kelompok mempresentasikan hasil diskusinya dan kelompok lain menanggapi hasil diskusi kelompok yang tampil. Langkah terakhir adalah melakukan refleksi untuk melihat hasil pelaksanaan pembelajaran; yang dapat dijadikan bahan refleksi untuk menganalisis data yang diperoleh serta menyimpulkannya. Hasil kesimpulan sebagai acuan untuk merencanakan tindakan pada siklus berikutnya atau jika sudah mencapai kriteria tindakan tidak perlu diulang kembali. Target penelitian adalah 25 orang menunjukkan aktivitas belajar yang tinggi, hasil belajarnya mencapai rerata 80 , dan persentase keberhasilan tindakan mencapai 77 dalam kategori baik.

Gambaran siklus Penelitian Tindakan Kelas yang dilaksanakan model spiral dari Kemmis dan Taggart (Hopkins, 1993) sebagai berikut.

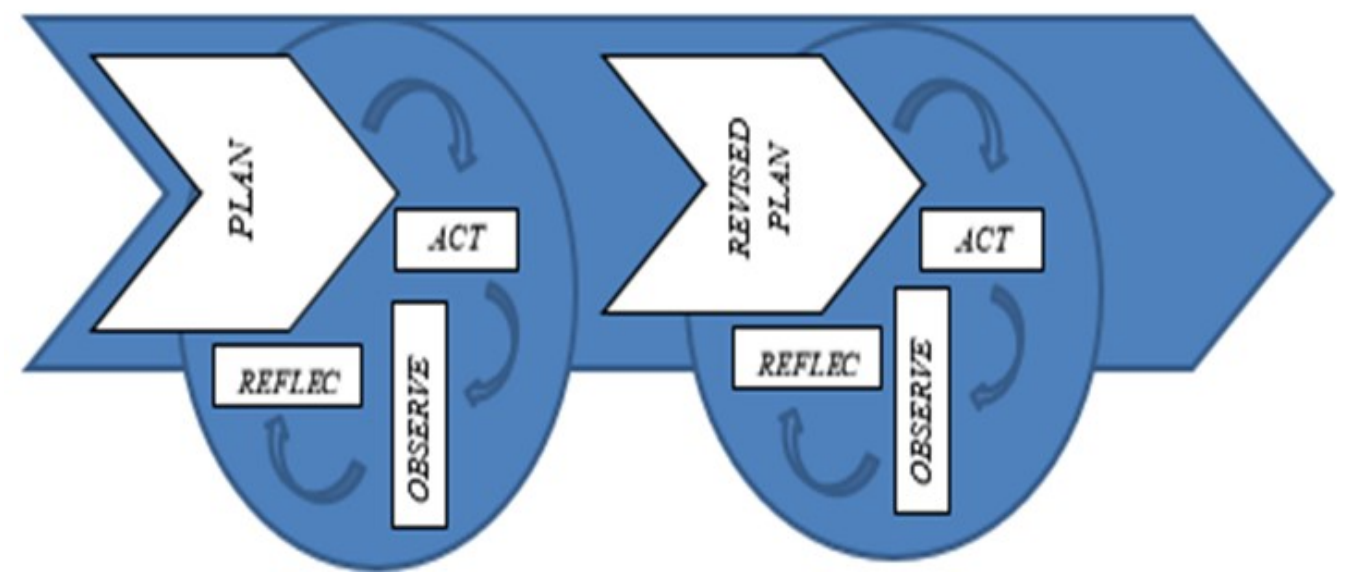

Gambar 1. Siklus Penelitian Tindakan Kelas

Sumber: Hopkins, 1993

\section{HASIL DAN PEMBAHASAN}

Dari hasil observasi awal/pendahuluan aktivitas belajar peserta didik dalam kategori rendah dengan rerata 47,2. Yang ditandai dengan hanya 12 orang saja $(37,5 \%)$ yang menunjukkan aktivitas belajar tinggi; sebaliknya lebih dari setengah dari seluruh peserta didik yakni 20 orang $(62,5 \%)$ menunjukkan aktivitas belajar rendah. Hal tersebut berpengaruh terhadap hasil belajarnya, dengan rerata hanya mencapai 57,55 dalam kategori kurang. Sejumlah 23 orang $(71,89 \%)$ menunjukkan hasil belajar di bawah Kriteria Ketuntasan Minimal (KKM). 
Berdasarkan hasil penelitian setelah dilakukan tindakan dengan menggunakan media pembelajaran "Sipete" pada Siklus I aktivitas belajar peserta didik mengalami peningkatan meskipun hanya sedikit dibandingkan dengan observasi awal/pendahuluan; sejumlah 15 peserta didik (46,88\%) yang menunjukkan aktivitas belajar tinggi dan sebaliknya 17 orang $(53,12 \%)$ menunjukkan aktivitas belajar rendah dengan persentase keberhasilan mencapai 57 dalam kategori cukup. Pada Siklus II mengalami peningkatan dari 15 peserta didik menjadi 23 orang $(71,88 \%)$ yang menunjukkan aktivitas belajar tinggi dan tinggal 9 orang $(28,13 \%)$ dengan aktivitas belajar rendah. Keberhasilan tindakan mencapai rerata 73 dalam kategori baik. Siklus III sejumlah 27 orang $(84,38 \%)$ sudah menunjukkan aktivitas belajar tinggi hanya tersisa 5 orang $(15,63 \%)$ yang menunjukkan aktivitas belajar rendah dengan persentase keberhasilan mencapai 82 dalam kategori sangat baik. Tentunya pada Siklus III menunjukkan bahwa target sejumlah 25 orang yang menunjukkan aktivitas belajar tinggi telah terlampaui; demikian pula dengan persentase keberhasilan yang melampaui target 77 . Dengan demikian disimpulkan bahwa penggunaan media pembelajaran "Sipete" dapat meningkatkan aktivitas belajar.

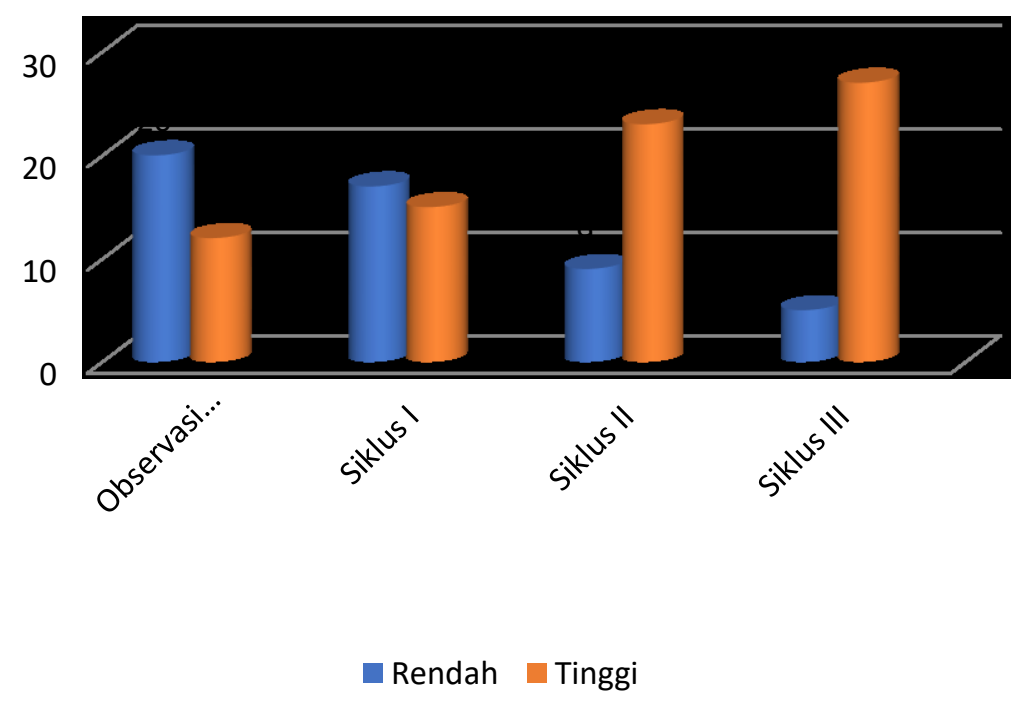

Grafik 1. Aktivitas Belajar

Tabel 1. Taraf Keberhasilan Aktivitas Belajar

\begin{tabular}{lllll} 
Persentase Keberhasilan Tindakan & Observasi awal & Siklus I & Siklus II & Siklus III \\
\hline Rerata & 47,2 & 57 & 73 & 82 \\
Kategori & Rendah & Cukup & Baik & Sangat Baik \\
\hline
\end{tabular}

Peningkatan hasil belajar mengalami peningkatan secara signifikan; seiring dengan peningkatan aktivitas belajar dari siklus ke siklus. Pada Siklus I rerata hasil belajarnya mencapai 66 dalam kategori cukup. Rerata hasil belajar pada Siklus II adalah 75 (kategori baik), dan Siklus III rerata menunjukkan 82 (kategori sangat baik).

Hasil penelitian pada Siklus I aktivitas belajar hanya meningkat sedikit yang disebabkan peserta didik sibuk melihat-lihat dan menikmati tampilan simbol-simbol peta yang menarik dengan paduan warna yang cantik sehingga "Sipete" kurang optimal digunakan dalam pembelajaran. Apalagi simbol-simbol peta ditempatkan di atas meja yang berada di tengah ruang kelas; yang pada akhirnya menimbulkan kerumunan kecil akibat peserta didik berebut untuk mendapatkannya. Waktu tersita karena kegiatan tersebut yang sekaligus menyebabkan kelas kurang kondusif. Tentunya berpengaruh terhadap kelompok yang mempresentasikan hasil diskusinya, waktu yang dimiliki hanya sedikit serta tidak mendapatkan kesempatan secara 
maksimal dalam memanfaatkan "Sipete". Hanya tiga dari delapan kelompok saja yang mempresentasikan hasil diskusinya akibat keterbatasan waktu. Pemahaman peserta didik terhadap materi sangat sedikit; hal tersebut berpengaruh terhadap perolehan hasil belajarnya. Oleh karena aktivitas dan hasil belajarnya dalam kategori cukup; maka perlu diadakan perbaikan pembelajaran pada Siklus II.

Pada Siklus II aktivitas belajar mengalami peningkatan signifikan karena peserta didik aktif bertanya dan mampu memanfaatkan "Sipete" untuk membantu memahami materi pembelajaran. Media pembelajaran tidak dipusatkan di satu meja; akan tetapi masing-masing kelompok mendapatkan satu paket berisi 52 simbol peta. Tentunya masing-masing kelompok lebih optimal memanfaatkan "Sipete". Presentasi masing-masing kelompok semakin merata serta tidak hanya didominasi oleh sebagian kecil kelompok saja. Seluruh kelompok dapat mempresentasikan hasil diskusinya. Tanggapan dari kelompok lain mulai bermunculan sehingga kelas 'lebih hidup'. Tentunya sangat berpengaruh terhadap aktivitas serta hasil belajarnya yang meningkat dalam kategori baik. Meskipun kategori aktivitas dan hasil belajar sudah meningkat; akan tetapi karena belum mencapai target penelitian, maka diadakan perbaikan lagi pada Siklus III.

Aktivitas dan hasil belajar IPS peserta didik pada Siklus III melampaui target penelitian bahkan mencapai kategori sangat baik. Pencapaian tersebut sebagai akibat proses pembelajaran lancar, kelas kondusif, penggunaan media pembelajaran "Sipete" secara optimal oleh masingmasing peserta didik bukan hanya secara perwakilan kelompok semata, seluruh kelompok mendapatkan kesempatan untuk mempresentasikan hasil diskusinya, serta tanya jawab dan tanggapan kelompok lain secara merata dengan sangat baik.

\section{SIMPULAN}

Berdasarkan hasil penelitian membuktikan bahwa penggunaan media pembelajaran "Sipete" mampu meningkatkan aktivitas dan hasil belajar peserta didik. Terbukti dari masing-masing siklus menunjukkan peningkatan secara signifikan. Pada Siklus I aktivitas belajar yang semula hanya 15 peserta didik $(46,88 \%)$ yang menunjukkan aktivitas belajar tinggi dengan persentase keberhasilan mencapai 57 dalam kategori cukup, meningkat menjadi 23 orang $(71,88 \%)$ pada Siklus II dengan keberhasilan tindakan mencapai 73 dalam kategori baik. Pada Siklus III meningkat menjadi 27 orang (84,38\%) yang menunjukkan aktivitas belajar tinggi dengan persentase keberhasilan mencapai 82 dalam kategori sangat baik.

Hasil belajarnya mengalami peningkatan secara signifikan pula, yang ditandai dengan rerata pada Siklus I hanya mencapai 66 dalam kategori cukup; Siklus II meningkat menjadi 75 (kategori baik), dan akhirnya pada Siklus III rerata menunjukkan 82 (kategori sangat baik)

\section{DAFTAR PUSTAKA}

Azhar Arsyad. 2011. Media Pembelajaran. Jakarta: Rajawali Pers.

Dimyati, Mudjiono. 2009. Belajar dan Pembelajaran. Jakarta: Rineka Cipta.

Hopkins, D. 1993. A Teacher's Guide to Classroom Research. Philadelphia: Open University Press.

Peraturan Menteri Pendidikan dan Kebudayaan Nomor 22 Tahun 2013 tentang Standar Proses. 
Purnomo, A., 2017. Pengaruh Pembelajaran Outdoor terhadap Pengetahuan, dan Sikap Pelestarian Lingkungan Mahasiswa S1 Pendidikan Geografi Universitas Kanjuruhan Malang. Jurnal Pendidikan Geografi: Kajian, Teori, dan Praktek dalam Bidang Pendidikan dan Ilmu Geografi, 20(1).Sumaatmadja, N. 2007. Konsep Dasar IPS. Jakarta: UT.

Tim Penyusun Kamus Pusat Bahasa. 2002. Kamus Besar Bahasa Indonesia. Jakarta: Balai Pustaka.

Wiriaatmadja, R. 2009. Metode Penelitian Tindakan Kelas. Cetakan kedelapan. Bandung: PT Remaja Rosdakarya 